\title{
History of History of Physics
}

\author{
Stanislav Južnič \\ Dunajska 83, \\ Ljubljana 1000, Slovenia \\ E-mail: juznic@hotmail.com
}

\begin{abstract}
The twelve decades of modern academic history of physics have provided enough material for the study of the history of history of physics, the focus of which is the development of the opinions and methods of historians of physics. The achievements of historians of physics are compared with the achievements of their objects of research, the physicists. Some correlations are expected. The group of historians-researchers and the group of their objects interacted. In several cases, the same person started out as a researcher and later moved on to the field of researcher of research achievements. There are also some competence-related quarrels between the two groups, the historians and the physicists.
\end{abstract}

The new science called history of history of physics could be useful in a special case study of Jesuits. Jesuit professors formed a special group of physicists and historians studying the physicists, who were very influential in their time. Jesuits, except the very best of them such as Rudjer Bošković, Athanasius Kircher, or Christopher Clavius, were later omitted from historical surveys by their Enlightenment opponents. In the second half of the $19^{\text {th }}$ century, Jesuit historians produced a considerable amount of useful biographies and bibliographies of their fellows. This makes them an interesting research subject for the history of history of physics as one of the best researched scientific-oriented networks worldwide, especially the Jesuits who were active in China.

Keywords: history of history of physics, Jesuits, physics in the Far East, Rudjer Bošković, Thomas Kuhn 


\section{Introduction}

The main aim of this study is very ambitious as it tries no less than to establish a brand new science called the history of history of physics. The twelve decades of modern academic history of physics have provided enough material for the history of history of physics. The need for such a new branch of historical studies inside the humanities is obvious. History of history of physics will guide researchers and redefine their goals towards the focuses of worldwide research interests.

History of history of physics is a branch of history of history of sciences. The Chinese did not have a proper word for mechanics before the translations of Wang Zheng (王徵, 1571-1644) and Johann Schreck Terrentius (1576-1630), and the Chinese word for physics as a whole was introduced even much later, as physics was the fundamental part of (Western) exact sciences up until the $3^{\text {rd }}$ millennium when the genome research probably surpassed it. Besides the history of mathematics and astronomy, history of physics was the most widely researched part of histories of sciences until recently. For those reasons, the new science of the history of history of physics should be introduced in the first place before other branches of histories of histories of sciences.

\section{Methodology}

History of history of physics is an interdisciplinary field that defies classification, just like history of physics as its subject of research. It is a meta-science of history of physics. The proposed new discipline should explain how the views on the history of physics have evolved historically, with an aim to explain the changes and the dynamics of changing in times and spaces of particular academic institutions. Its areas of study are historians of physics as well as their work and networks. The method it uses is historical narrative, as well as comparison between the approaches of historians of physics as the function of their times, geography of their Alma Maters, academic ancestors, institutions they belong to, and eventual changes in their approaches towards their history of physics during their research. 
The history of history of physics could help resolve the main apple of discord between Whig-oriented researching physicists and historians of physics, which is Konrad Lorentz's pecking order. Who is cleverer of both groups, who could better predict the future physics, and consequently, who should receive a greater salary? The dream of every historian of physics is to predict the future of physics. It could be upgraded to a dream of a historian of the history of physics to predict the future of the discipline he researches.

A researching physicist may feel like an experimental rabbit in the eyes of a historian of physics and it is far from obvious which of the two sciences is subordinated to another. Certainly we need the history of history of physics in which the role of experimental rabbits will pass on to historians of physics. There is no need for the history of history of history of physics as far as we could guess. One of the aims of the new field of the history of history of physics is to verify the hypotheses of sharing the social-professional-political environment between the two groups - the physicists and the historians of (modern) physics. Their sharing the same environment could force both groups to exchange their fundamental ideas in similar ways in similar spaces of time. Historians of physics may have a considerable delay because they need time to discuss newly emerging ideas of physics from a historical perspective. Historians of quantum mechanics were certainly influenced by the new approaches of physicists in 1900-1930, which at least in its German part were influenced by Paul Forman's idea of the questionable legacy of the Weimar Republic. The question is, did those changes also influence the historians of physics dealing with earlier periods? Historians usually have to wait some time to get the historical perspectives of the events they are going to examine. Is that delay a constant space of time? Does the delayed research of the histories of quantum relativity cause a delay in research of contemporary not-subatomic and much-slower-than-light physics in the years after the quantum mechanics and theory of relativity won the day? If the discoveries of contemporary physics influence all kinds of its historians, do the discoveries of the contemporary history of physics give feedback on researching physicists, for example with the data about Newton's alchemical research, Popper's falsifications rule, or Kuhn's paradigms? Most historians of physics before Rupert Hall received at least graduate training in sciences, but almost no physicist bother to get a degree in history of physics for his physics research. Anyway, the most important concepts of history of physics could not pass completely unnoticed in the physicists' community. Last but not least, we all read the same public journals and the web, share the same world. 


\section{The authorship of histories of physics}

History of physics was part of ordinary textbooks and curricula before the journal communication and wireless revolution of Fin de Siècle. The producers and authors were researching physicists and even more often teaching physicists, in many cases both in the same person. The situation changed with the rapid development in the area of communications in the $20^{\text {th }}$ century. It soon opposed the profession of historian of physics to the Whig histories of physics, which were narrated in a logical order to help the pedagogical process in which most researching physicists were involved. The relation changed again in the $3^{\text {rd }}$ millennium when non-teaching researchers in institutes and industrial jobs outnumbered professors, and the Logic-Whig approach was proved to be almost false or at least bending the truth. The (honorable) ends no longer justify the (false) means. The history of physics is part of the humanities which is on the other side of the eternal war of two separate worlds which keeps the Whig approach alive. The professionalization of a historian of physics makes him equivalent to physicists, so might he also polish the truth to facilitate the teaching process? Could he also modify the historical reality to fit better his proposed theories?

There were often historians of physics and historians of particular branches of physics who were connected or were even identical with their researching fellows. The history of physics is in deficit to the related histories of mathematics or astronomy because there is no relevant web list of historians of physics thus far, and academic trees of mathematicians are far more elaborate.

The history of history of physics should beware of Eurocentrism and of praising the theoretical or experimental contributions of physicists over the industrialtechnological ones. In fact, historians of (physical) engineering are aware of their different method of research of the past, and of engineers' different research tools. In 1999, the peripheral historians of physics (of sciences) already established their own organization called STEP (Science and Technology in the European Periphery) in Barcelona with huge support from the Iberian Peninsula and Greece. Later also Japanese and other Non-European researchers joined the group. 


\section{Definition of objects and their research limitations for a historian of history of physics}

The theories, experiments or technological improvements of history of physics deal with concrete facts in the research of physicists, although the technological history of physics could be associated with management in the sense that James Bryant Conant's helped the academic careers of Thomas Kuhn or Willard Van Orman Quine (1908-2000) in Harvard (Collins, 1998, p. 1017). That way, the experimental history of physics would equal its historiography with the included biographical and bibliographical work, and theoretical history of physics should include Popper, Kuhn, Lakatos, or Feyrabend. The latter would therefore nearly equal philosophy of physics. That promising approach would bring Eudemus of Rhodes or even Erastosthenes to the early camp of theoretical history of physics with their rare descendants before Ernst Mach.

The technological and managing of the history of physics could involve powerful patrons focused on modern research of scientific patronage of rulers and important politicians, such as Guericke, as well as Kircher, and Francis Bacon translator's patron Prince Johann Weikhard of Auersperg (1615-1677). The wealthy patrons always financed-managed physics research and switched to patronizing history of physics only recently, with Maxwell's Cavendish Cambridge program of publishing Henry Cavendish's (1731-1810) papers in 1879, or Conant's popularizing of science through history of science. The present research of the history of history of physics does not cover patronage of history of physics to that extent. It mostly covers the historiography of physics and to a limited extent the philosophy of physics in the sense of Kuhn-Popper-Feyerabend which was very close to the history of physics. The history of history of patronage of research in physics is an interesting field for some future research.

Which works should a historian of history of physics examine? The historian studying the work of physicists is defined as dealing mostly with the old achievements and only to the lesser degree with the probable research of the author himself or his contemporaries. In that scope, Joseph Priestley still wrote the history of science even though he included his own and his fellows' achievements. The old-fashioned textbooks with long historical introductions or the modern textbooks with short historical anecdotes do not meet the criteria for the history of scientific work in physics. Philosophy of physics include some historical aspects, as seen in the works of Popper, Lakatos, Ziman, or Kuhn, but purely logical-philosophical reconstructions of the physics of the past do not 
meet the criteria of a work of the history of physics. A reprint of historical sources is not automatically a work of history of science, for example Charles Babbage and Baron Francis Maseres's publication of Gregory, Descartes, Huygens and I. Barrow's tracts on optics in Scriptores Optici, printed in 1823. Surprisingly, the early English histories of optics were connected with photography in the 1850 s, such as the photographic instrument maker of London William Henry Thornthwaite's (1819-1894) A Guide to Photography containing concise history of the science and its connection with Optics in London in 1851 or surgeon Jabez Hogh's (1817-1899) similarly entitled A Practical Manual of Photography containing concise history of the science and its connection with Optics in London in 1854. The pure histories of optics followed later, also with Edmund Whittaker's history of ether in 1910.

The popularizing works do not automatically belong to the achievements of the history of science. Voltaire's semibiographical description of Newton's work as well as his lover Émile de Châtelet's translation of the Principia contributed to the history of physics, while their friend Francesco Algarotti's (1712-1764) popular work on optics Newtonianismo per le dame (1737) or the popular updated additions of Newton's achievements to Jacques Rohault's (1618-1672) textbook Traité de Physique (1671) were not important achievements in the field of history of physics, although they made important contribution to physics itself. According to that criterion, Newton quickly found his biographers, historians of science, who included Newton's niece's famous falling apple story. Among those were the Frenchman Fontanelle, the British Colin MacLaurin, or the Italian Paulo Frisi. Newton's earliest biographers were Fontanelle and Voltaire, whose works were translated into English almost immediately. Galileo's works were worldwide bestsellers, but papal condemnation of Galileo delayed some of his Italian biographers until the Barnabite monk Paolo Frisi published on Galileo in Saggio sul Galileo (1765) and in Milano journal Il Café in 1775. Giovan Battista Clemente Nèlli (1725-1793) published the voluminous Galileo's biography only in 1793 in more liberal Swiss Losanna to popularize Viviani's Vita-memoires printed in Galileo's Opere in Florence in 1717. Viviani acted as a monopolist on his teacher Galileo's biographies when he tried to prevent the Jesuit Athanasius Kircher's (positive) Galileo's eulogy from being published in what became the later lost Etruria Illustrata of 1678, or in an attempt to prevent the publishing of his former student Lorenzo Magalotti's (1632-1717) Amsterdam correspondence between Galileo and Paolo Scarpi in 1673. Voltaire included Galileo into his Dictionnaire Philosophique in 1754, but in the same year Diderot and Frisi's patron D'Alembert dared only to mention Galileo in their encyclopedia's entry 


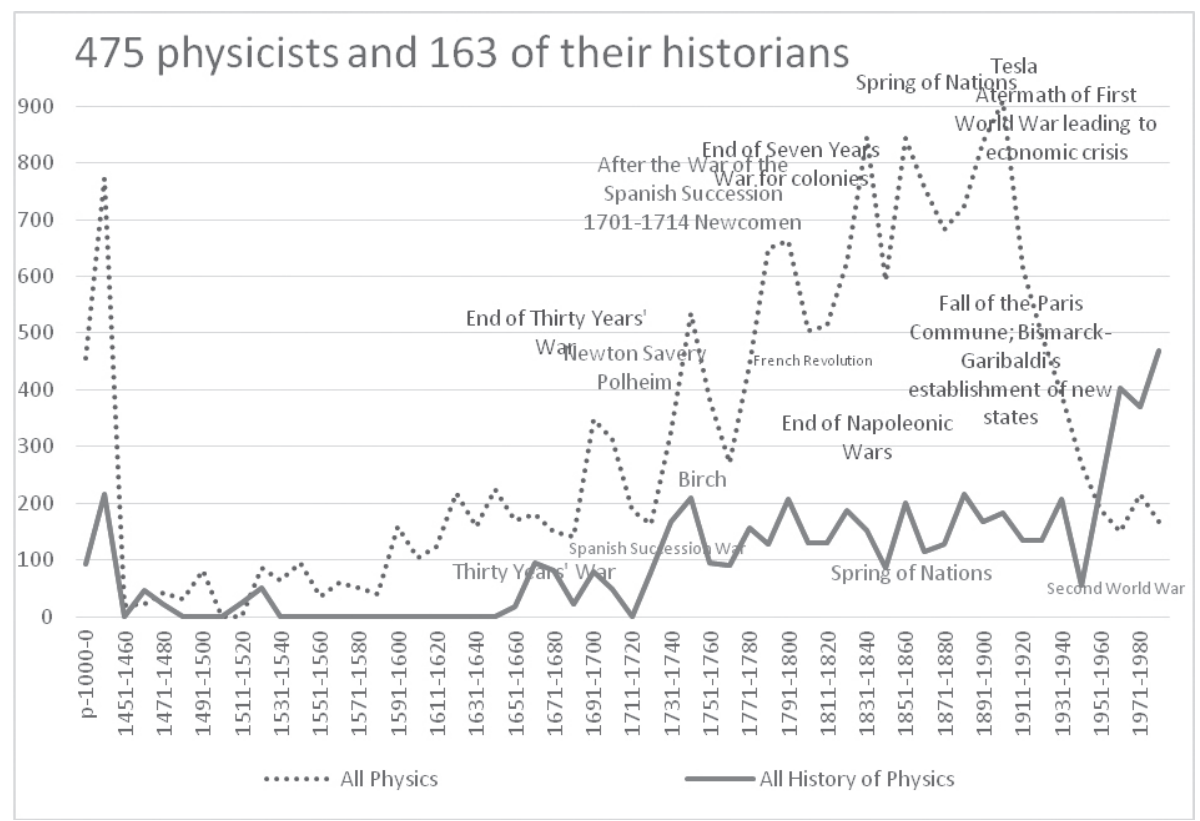

Figure 1. Physicists and their historians

on Copernicus (Segre, 1998, pp. 394-395, 422, 424, 452). While Newton's biographers started their work six decades after his publications, Galileo's biographies by Vivani and Nèlli took eight- or even seventeen decades. Besides Galileo, Tesla held the record because his experimental technology of energy transfer became extremely popular dozen decades after his initial proposal, which was crowned with his fruitless tower near New York City. Even Tesla's theories, including the almighty ether, are being reconsidered by his modern fans in spite of Einstein's dislike of ether.

Newton's great discoveries were followed by nearly three quarters of a century of intellectual stagnation, especially in England. Already John Fredrick William Hershel junior and his friend William Whewell knew that very well. About half that long was the crisis during the declination and suppression of Jesuits when the European political energy was focused on preparing for the French revolution. It was the era of technical innovations of the craftsmen of the English Industrial Revolution, but the experimental and theoretical physics stagnated, and so did their histories. For a while, the classical education lost its values especially among the British and Dutch sailors and craftsmen like Richard Arkwright, and, again, in the era of Faraday-Edison-Tesla's electronics, early computers, or modern web- 
oriented smartphones. Another three quarters of a century passed before the realistic historical valuation of the building of quantum mechanics and theory of relativity was provided between the years 1905 and 1975, although tons of textbooks and propaganda texts emerged in the meantime. The new bishop Thomas Birch (1705-1766) will probably save the day in the $3^{\text {rd }}$ millennium with the commented notes on Tesla-Einstein-Bohr's quarrels on Tesla's idea of wireless distribution of energy.

WorldCat is not the best tool for research into history of history of physics because its keywords also yield the physics works of the tagged period, not only the histories of it. The old biographical encyclopedias such as those by Asimov (1978), Bogolyubov (1983), Khramov (1977), Grigoryan and Fradlin (1982, pp. 216-257), and Brush (1976), or personal communication and reading of such materials offer better insight.

It is even more difficult to properly approach the early histories of technologies in an attempt to develop the history of history of industrial physics. Louis XIV le Soleil's military architect Bernard Forest de Bélidor (1697-1761) wrote his nicely illustrated survey of water-powered machines including steam engines as early as in 1727-1790, and Christian Wolf (1679-1754) provided the early German translation of it in 1743-1771. In 1729, Bélidor published on engineering science, including Galileo, Mariotte, and his own work. The Habsburg director of hydraulic works, appointed in 1783 to replace Gabriel Gruber, ColonelLieutenant Sebastian de Maillard (1746-1822) won St. Petersburg Academy's award in 1783 with a discussion of Watt's innovations, among other things. He published his ideas in Vienna and Strasbourg in 1784. William Blakey's (1712-1792) Observations sur les pompes à feu, published in French in 1777, and his A Historical Account, printed in London posthumously in 1793, were the earliest books on the history of steam engine. Bélidor, Maillard, and Blakey were true historians and insiders. Blakey personally developed Savary's type of steam engines and competed with Newcomb's machine. Professor of the prestigious Paris Polytechnic from 1795 to 1815 Gaspard Clair Francois Maria Riche de Prony (1755-1839) of the revolutionary and Napoleonic period, became famous for the hydraulic brake named after him. He organized the calculating and printing of decimal trigonometric tables and managed great hydraulic enterprises to publish the first course in mechanics with the coordinate system including steam engines in 1790 and 1796 in the German translation Neue Architectura Hidraulika, printed in Frankfurt in 1795 and 1801. After Napoleon's exile, Prony kept his position at the Academy, unlike Lazare Carnot, and was familiar 
with the report by Lazare's son Sadi Carnot, but he did not give any feedback to it. The unfortunate pioneering engineer and architect of steamers on the Thames George Dodd (1783-1827) and Irish topographer and traveler Isaac Weld (1774-1856) provided one of the earliest accounts of steamboats on the London Thames, Glasgow, and the surroundings of Dublin in their A Historical and Explanatory Dissertation in 1818. They discussed the advanced use of steam engines. David Brewster's compilation of John Robison's work with comments by James Watt, entitled $A$ System of Mechanical Philosophy, published in 1822 in Glasgow, was another insider's story. An early non-engineer in the field of history of steam engines was Charles Frederick Partington, who died around 1857. He earned his livelihood as a librarian at the Royal Institution and successfully lectured with his An Historical and Descriptive Account of the Steam Engine, which his printer Taylor published in 1822 in London. Aegidius de Wit (1800-1826) was promoted with his Latin dissertation on steam engines, Dissertatio physicomathematica de machina atmica, in Utrecht University in 1823, but he died soon afterwards. Robert Stuart (*1782?) was the pseudonym of an engineer and author of A Descriptive History of the Steam Engine. He copied Partington's style with patents and suggestions of boiling improvements, included in 1824, and T. G. Cummings published his work on the history of steam engines also in 1824. The Scottish engineer Robert Scott Burns (1825-1901) published his The Steam Engine in 1854. Therefore, Sadi Carnot was not late at all with his booklet in 1824 . The majority of discussions on steam engines were produced by working engineers and therefore Carnot's booklet was viewed as outsider of mainstream engineering of his day before Clapeyron's intervention. Clapeyron had just returned from his splendid lecturing isolation in St. Petersburg, which enabled him to take a broader view from a different perspective.

The dating of the work of historians of physics has proved problematic because many works on history of science as well as physics, including by Viviani and Châtelet, were published posthumously. Therefore, the author's year of death was considered more relevant in the history of history of physics, as the series of posthumous reprints could be endless.

Aristotle defined physics for the future generations, although its scope changed often in later centuries. The Early Modern physics emerged with Galileo but there were no histories of it up to his time. In fact, the English term Natural History and Faraday's self-identification as a philosopher provoked the (wrong) feelings that there is something historical-philosophical in fundamental physics or biology research. Modern astrophysics, in fact, entail big-bang-philosophical 
and theological aspects of seeing the light from remote stars which has been radiated at some distant historical moment. Modern astrophysics is a history, but on the cosmic level. It is not interested in particular personal or network histories. It is more in style of Marx's statement that all science is history because all that we did yesterday belongs to history.

\section{Previous researches in history of history of physics}

Randall Collins (*1941) provided some insight into the networks of Mach and Schlick in Vienna and Einstein and Reichenbach in the Berlin philosophical circle, whose members were the direct academic descendants or at least students of students of the leading physicists of the era. Moritz Schlick, head of MachBoltzmann's Viennese philosophical chair, was Planck's student who switched to Mach's side (Collins, 1998, pp. 722-723, 726, 730), where Planck also figured before his quantum theory and quarrels with Mach. Collins drew huge networks of intellectuals from all over the continents and millennia, and connected them in time and space, so that Neurath, a US immigrant from the Vienna Circle, even influenced Thomas Kuhn. He gave no preference to the Westerners which enabled Collins to avoid Eurocentrism (Collins, 1998, pp. 894-943, 944-946).

Modern network theorists expanded Collins's ideas with the use of sophisticated computer network programs which is also a path followed in this study. Marc Rothenberg published the encyclopedia of history of science and historians of science, medicine, and technology of the USA in 2001 (Rothenberg, 2001). In the area of history of science, Christina Chimisso from The Open University in the United Kingdom recently added the history of French philosophy of science (Chimisso, 2016). 


\section{History of history: humble beginnings with Jesuits' intermezzo}

The Chinese used to produce the histories of their scientific and observational achievements for the court all the time. Researchers in India did the same, while the Maya or the Incas produced no relevant memories to provide us the names of their agricultural innovators because they did not use writing and recording in the sense of the Old World. They were different, but that does not mean that they could not be better in some aspects of history of physics, for example in their uses of compass.

Eudemus of Rhodes and after him the Alexandrian librarian Erastosthenes of Cyrene are sometimes cited as the pioneers of history of science owning to Eudemus's clever remarks on past sciences which went beyond pure factcollecting. The astrolabe maker Al-Saghani, Al-Biruni (Abu Reihan Muhammed ibn Ahmed, *973), Avicenna, Averroës, or their Muslim or Far East fellows probably rarely made such evaluated comments even when they were discussing the older achievements as historiographers. The pioneering modern European historian of electricity (in 1775), light (in 1772) and pneumatic was Priestley, the first modern historian of astronomic observatories was Jean Bernoulli in his letters dated to 1768-1769, and the first modern historian of mathematics with many applications in physics (1799-1802) was Jean-Étienne Montucla. Certainly, all of them were researching physicists. Priestley and Bernoulli, in fact, described the work of the people they personally collaborated with. It is remarkable that Priestley provided the histories of particular branches of physics and chemistry research before the general ones became available, which was the consequence of the quick growth in both fields that Priestley covered. No textbook of his time covered such quickly developing material, and Priestley, in fact, published a textbook with updated ongoing research, mentioning also history. Everybody used Priestley's work in the decades to come the same way as everybody later used Faraday's diaries.

In 1837, William Whewell dedicated to J. F. W. Herschel his histories of inductive sciences to cover Whewell's and Herschel's awareness of the decline of physics in England after Newton. The Habsburg astronomer Joseph Johan von Littrow (1781-1840) translated it for a posthumous publication in 1840-1841. Whewell's and Herschel's work was a kind of history of broader physics with political ambitions. Belgian Jesuits Augustin de Backer and Carlos Sommervogel (1890-1900), Hungarian Jesuit Ladislaus Lukács (1988), and Austrian Jesuit 
Johann Nepomuk Stoeger (1855) provided bibliographical studies of their fellow brothers which were not concentrated on exact sciences, but are very helpful for a historian of physics. The Jesuit professors of physics and mathematics developed a special kind of network of physicists. They were very powerful in their time, but after Jesuit suppression the Jesuits were excluded from the historical surveys of the winners except the very best of them such as Bošković, Athanasius Kircher, or Clavius. After their quarrels with Galileo, Jesuit networks in the form of philosophical societies developed their physics and its history in opposition to the mainstream. The Modern American Jesuits and their fans contributed significantly to the history of Jesuits' physics in the final decades of the $2^{\text {nd }}$ millennium, and such case studies became extremely popular again after the inauguration of Pope Francis and the $200^{\text {th }}$ anniversary of the restoration of Jesuits. In fact, there are several histories of physics that a historian of history of physics should take into consideration, roughly speaking the history of physics of the winners, and the networks on the losing sides among the white Western Christians, as well as among non-whites.

For the German-speaking world, Ernst Mach provided philosophically oriented histories of all branches of physics (in 1883-1912 on mechanics, in 1894 on the Doppler effect of acoustics and colors, in 1909 on the first law of thermodynamics, in 1919 on heat, in 1921 on optics, see Mach, 1894; 1909; 1912; 1919) and, to a lesser degree, of electromagnetism, possibly because electromagnetism was not directly connected with any of the five human senses (vision, hearing, taste, touch, heat, and balance, which was added later). The antagonist of Friedrich Engels, deaf physicist Eugen Dühring published the history of mechanics in 1873, Seyfert provided Geschichte des Galvanismus, and Wilhelm Weber's student Edmund Hoppe discussed electricity in 1884. The Danish daughter of Niels Bohr's teacher Bjerrum, Kristine Meyer, wrote the history of temperatures in 1913, Emil Wilde provided history of optics in 1838, Rudolf Clausius fought for his priority in 1852, and Ignaz Weiner discussed research of heat in 1863. Wilhelm Weber introduced the development of electric measurement without the history mentioned in 1864, Felix Klein published his history of nineteenthcentury research, and Maurice Cantor with collaborators provided the histories of mathematics together with applied physics in 1901-1913. The histories of all physics were published by J. C. Poggendorff in 1879, A. Heller in 18821884, and E. A. W. Gerland and Traumüller in 1892 and 1899. Ferdinand Rosenberger focused on the history of physics in 1882-1890, and the Real School professor Adolph Kistner in 1906. Ostwald organized the publication of the classical texts of exact sciences. Sir Edmund Whittaker published the history 


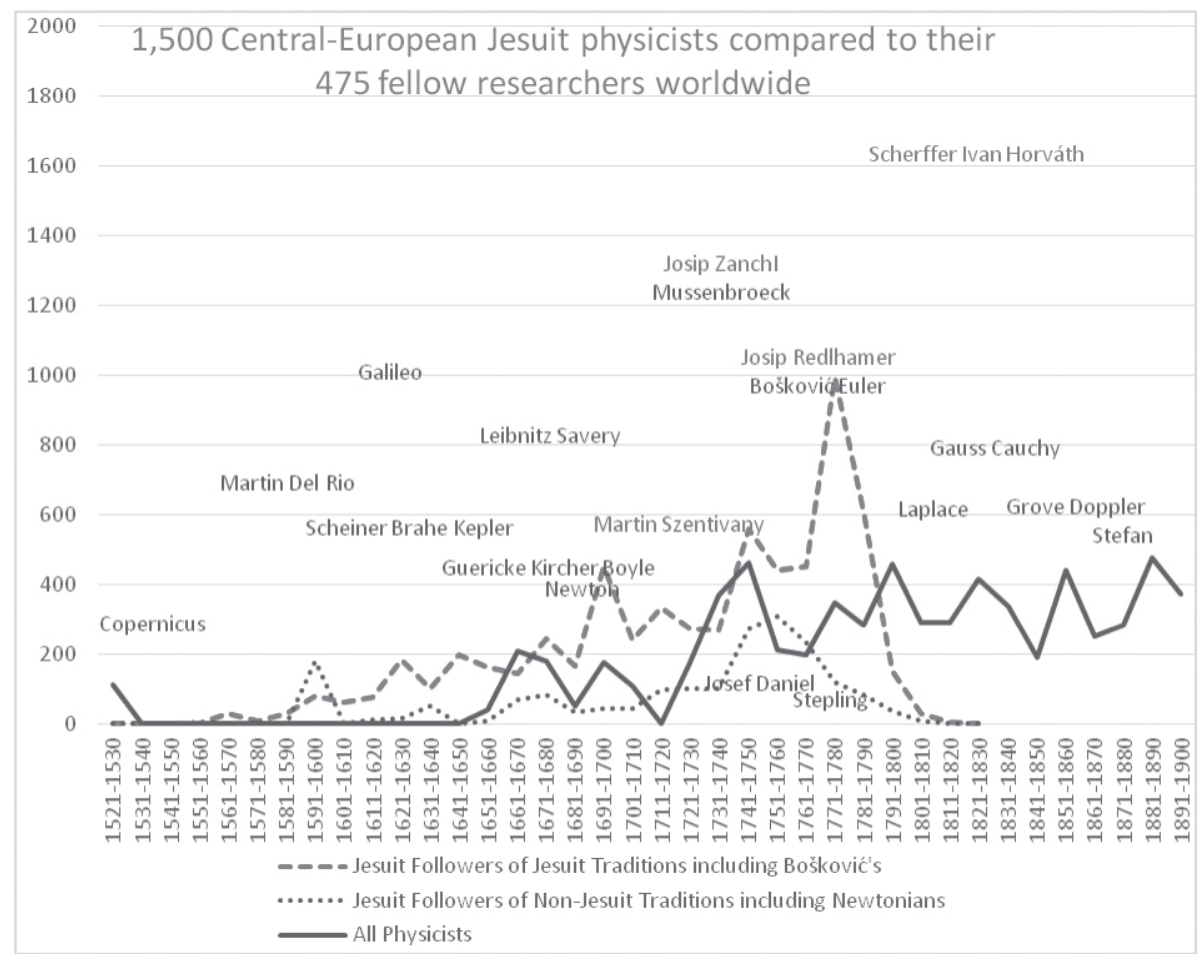

Figure 2. Comparison of Central-European Jesuit physicists and their fellow researchers worldwide

of ether in 1910. Nearly all relevant authors were physicists-for example, the Parisian industrial engineer turned science-fiction author Pierre Devaux wrote his Histoire de l'électricité in 1941 and 1954. The researchers merging in the mid-20 $0^{\text {th }}$ century include the physicist Vasco Ronchi's Luce, published in 1952. New professional positions for historians of sciences developed after Henry Guerlac of Cornell University taught Marie Boas Hall in 1977-1979 and the French-born Roger Hahn in 1957-1960. Robert Kargon also finished his studies of history in Cornell University. In 2007, the Japanese historian of astronomy Shigeru Nakayama (1928-2014) published in Historia scientiarum of Japan his reminiscences on Thomas Kuhn from the Harvard University. The other historians of physics include Geber, Scheele, Erastosthenes, Pliny the Elder, Agricola, J. F. Montucla, Jean Bernoulli with his letters in 1768-1769, Priestley, Percy Dunsheath's electric engineering history, A. P. Usher, Maurice Goldsmith, and Andreas Kleinert in Germany in 2005. 


\section{History of science as an academic discipline}

Nikola Tesla appeared at his famous show in Paris in March 1892. In the same year, with the support of Auguste Compte's (1898-1957) followers, the very first Chair of General History of science was created at Collège de France in Paris. Compte himself did not succeed in his lifetime, despite the fact that the traditions of the French history of science date back to Voltaire and Condorcet. Although the Paris Chair was closed in 1913 and had very limited impact compared to the philosophy of science (Chimisso, 2016, p. 85), it opened the field to academic approach. Twelve decades of modern academic history of science, and history of physics as part of it, provided enough material for the history of history of physics.

The history of physics was recognized as a research field inside the history of science. The historians of science with George Sarton established Isis, one of its most renowned journals in 1912 in Belgium. The early congresses of historians of science were held after the First World War in parallel to Solvay's Conferences, although nobody attended both. It was never safe to be a historian of science-for example, the Soviet delegation led by Bukharin and Edinburgh-educated Hessen at the $2^{\text {nd }}$ History of Science London congress of 1931 faced the deadly Stalinist squads five years later. After the Second World War, the American diplomat and chemist James Bryant Conant from Harvard, who served in Germany, propagated his subordinate Kuhn's history of science to strengthen the force of scientific ideology against Paul Feyerabend's anarchistic kicking of scientific arguments and ideology out of (state) schools (Conant, 1955, p. 55; Jammer, 1957 , p. 16). During the turbulent flower-power anti-Vietnam war protests, of the post-McCartney's cold war period, Kuhn's incommensurability paradigms, his antagonist Popper's falsification criteria, and Feyerabend's epistemological anarchy opposed to both entered the front pages of public opinion for the first time. Their argumentation of history of physics was shaped on philosophical premises. This stage, called the Popper-Kuhn-Needham's third revolution of history of physics' paradigm, brought the academic discussions into public awareness and soon fulfilled Conant's dream of establishing history of science as an academic discipline with dozens of chairs in Middle-East or US universities. However, much fewer of these were founded in Europe, where the histories of Whig research physicists still dominate despite the fact that organizing European History of Science congresses were started in the $3^{\text {rd }}$ millennia. The fourth paradigm of history of physics follows Needham's extra-European and 
female physicists contributions with Feyerabend's ideas included. Feyerabend as a Wehrmacht-Luftwaffe soldier was on the losing side in the Second World War. He fought against Kuhn's radar work in England that was hostile to Feyerabend, but Feyerabend proved to be victorious in the aftermath.

The historian of history of physics should compare the achievements of historians of physics with the achievements of his objects of research, the network of physicists. Some correlations are expected. The group of researchers and the group of their objects interact. In many cases the same person acted as a researcher and later as a researcher of the research achievement. There are also some competence-related quarrels between both groups. The historians of physics have many women in their group while female physicists are still comparatively rare. Also, historians of physics from the developing countries are much more frequent compared to their fellow countrymen physicists, also because research into history of physics is less expensive compared to that of experimental physics.

Let us try to build a five-stage paradigmatic development (growth-disintegrationuniversality-crisis-revolution) for the branches of physics (mechanics, optics, electromagnetism, heat). The same could be done for the history of physics as its fifth branch, although at least in the US it belongs to the humanities. In this case there is no dilemma between the chicken and the egg: certainly physics was created before its history could be narrated. But the delay was eventually not a long one, and both were invented during the Antiquities. The Herodotus-style history of physics (science) which was paradigmatic before developed in the Greek Mediterranean almost immediately after Aristotle coined his world physics. The genesis of the first paradigm (G1) of history of physics took place in Pax Romana. The new paradigm grew (R1) through the peripatetic Plutarch-style collection of histories of great (antique) scientists in medieval Christianity, and in the notes of the Chinese astronomical bureau. The disintegration (Z1) followed the Byzantine Platonists' free-speaking challenge of Western Peripateticism of Agyropolus, the son of his student's student Francesco Maurolico and other Byzantines on their flight from Turkish assaults to safer Italy. Their contemporaries witnessed the new Gutenberg's printing press and Columbus's sailings over the oceans. The universal paradigm (U1) used the encyclopedic works on Diderot and D'Alembert's model and modern journals to accumulate the growing knowledge more quickly in a world of the first Industrial Revolution when time was becoming money. The crisis (K1) introduced the new science of electricity (magnetism) with insider Priestley's narratives. The first revolution (P1) forced phlogiston to fall under the attack of the caloric theory with the French King going under the guillotine 
of the Republic. Was the phlogiston royal and was the caloric republican? In any case, the revolutionary republicans beheaded them both, the King and Lavoisier, the chief supporter of the caloric. If Stahl, the inventor of phlogiston, had survived long enough, it is fair to suppose that he would have shared no better destiny. In that case, the French Revolution and the revolution in the history of physics (and chemistry) were almost simultaneous. Which caused which? The most surprising of all actors was Priestley. He commended the crisis with his histories of electricity, light, colors, and airs, but denied the existence of revolutionary caloric as the replacement of his beloved phlogiston up to his last days in the USA. Jesuit Bošković vehemently disliked Priestley's materialism, but he died too soon to deal with the new Lavoisier's caloric and left Paris and our world before he could share Lavoisier's destiny.

The following period of growth of the second paradigm of history of physics (R2) witnessed the French sciences' triumph over Napoleon's bayonets. The Napoleonic minister Laplace's triumph was based on Englishman Newton's ideas, while Napoleon was the most bitter enemy of England, which was one of the historical jokes. The historians of science Delambre and Arago were not completely on Laplace's side, especially Arago as the writer of obituaries of academicians. But they were still all Newtonians. The second Emil Wilde's disintegration of the paradigm of history of optics inside the history of physics (Z2) followed the English-French (Young and Fresnel) cooperative development of anti-Newton wave optics again in the middle of the war. Wilde was too cautious to discuss Fresnel's wave novelties. The history of physics profited from Whewell's analysis of post-Newton's English stagnation in sciences in spite of the spread of railways as the output of the Industrial Revolution. The second disintegration of the history of optics paradigm also reacted to the development of steam engines as their late echo. It was simultaneous with Sadi Carnot's more recent explanation of the working process of steam engines. Poggendorffs universal paradigm (U2) used the new electro-technic telegraph in the space of time between the Spring of Nations and the Paris Commune, and during the crisis (K2) authors already wrote under electric light. Just after the fall of the Paris Commune, the second revolution (P2) used Mach's methodological doubts in invisibles before the quantum relativity, and Hoppe still tried to promote the research of electromagnetism of his teacher Weber against the victorious, but mortally ill, Maxwell.

The third growth of history of physics (R3) developed with the focus of Rosenberger, Cantor, Felix Klein, Kristine Meyer on the case study of 


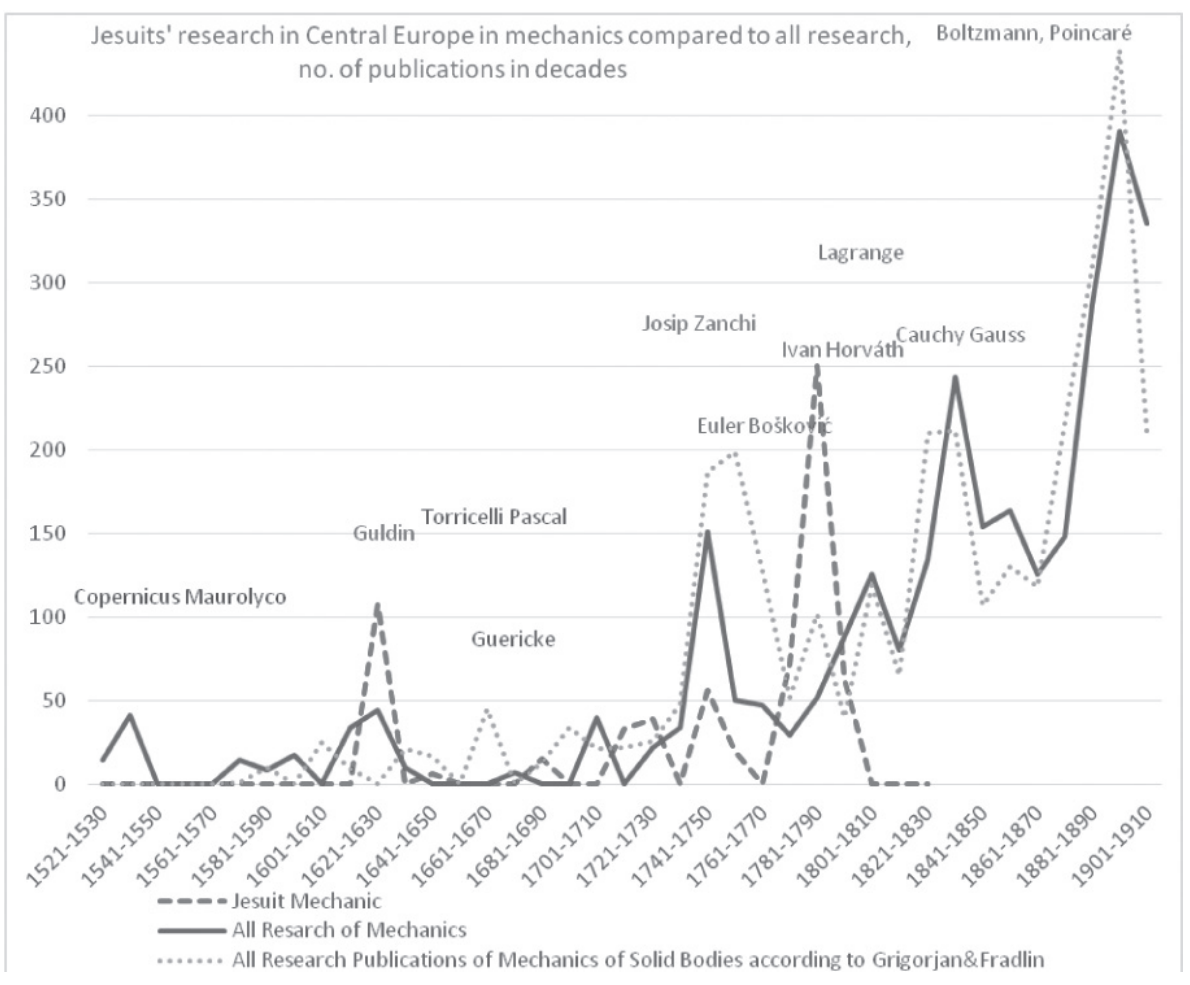

Figure 3. Jesuit's research publications in Central Europe through decades

temperature, and the historian of Wasan mathematics Yoshio Mikami (18751950) who was probably the most prolific researcher of the R3 era. In the overoptimistic style of Kelvin's clouds, it looked like physics would grow forever as nearly finished science, but quantum relativity simultaneously with the February Russian Revolution shook its foundations. Soon afterwards, Bohr's hydrogen atom, the general relativity, the First World War, and the October Revolution disintegrated (Z3) with Marxist environment, and the industry of automobiles involved among other novelties. Merton, Koyré, Ronchi's history of optics, Drake's Galileo, contribution by Jammer, Einstein's Jewish friend, and similar case studies enabled the universalization (U3) of the history of physics during the Cold War. Cohen, Lakatos, Yates's Renaissance, and Sivin's China of crisis (K3) enabled the early computer-based revolution (p3) of Kuhn's cold war of incommensurable paradigms, including Popper's falsification criteria. Joseph Needham's Chinese were competing with Europeans like his Chinese assistant 
competed with his English first wife. Brush, Truesdell, Fox, Shapin, Hahn, Xi Zezong, Pais, Darrigol, Kuhn's student Heilbron, and many others, built the new growth of history of physics (R4) which seems to be the greatest of them all.WIn the era of globalizing networks it will meet its disintegration destiny (Z4) with Feyerabend's anarchism, Kuhn's student Foreman's anti-causality in the supposedly illegal and questionable Weimar Republic for anti-Newtonian quantum mechanics, Ogilvie's studies of female physicists, or non-European studies in Shuntarō Itō's translation of Euclid, El-Bizri's discussion of Alhazen, and Al-Hassani's study of mechanical tools. Other novelties include the modern technical tools with the developed web and smartphones. The universalization of history of physics (U4) could be expected with women and non-Europeans slowly prevailing in the field of history of physics but not in the field of physics itself. The Needham's puzzle of supposed Christianity needed for industrial revolutions is questioned also because early Christianity disliked science, and probably the humanity and the positive role of industrial revolutions will soon become questionable. The new generations could accuse European colonialists for genocide, supported by the fact that colonialists' religion only needs belief and not benevolence to get to paradise. The God who forgives a sinful believer was a disaster formula for the Catholic crusades, Montezuma, Incas, colonies, and neo-colonies. The modern Chinese economic success questions the white Christian supremacy, as well as the history of physics based on its dictate.

Table 1. Five stages in the search for valuable history of physics

\begin{tabular}{|c|c|c|c|c|c|}
\hline & $\begin{array}{l}\text { Antiquities- } \\
\text { Middle Ages }\end{array}$ & $\begin{array}{l}16^{\text {th }}-18^{\text {th }} \\
\text { century }\end{array}$ & \begin{tabular}{|l} 
French \\
Revolution-Fin \\
De Siècle
\end{tabular} & $20^{\text {th }}$ century & Future \\
\hline Name & $\begin{array}{l}\text { Four substances } \\
\text { and fire/ether } \\
\text { variants }\end{array}$ & $\begin{array}{l}\text { Part of } \\
\text { research }\end{array}$ & $\begin{array}{l}\text { Textbooks } \\
\text { Appendixes }\end{array}$ & $\begin{array}{l}\text { History of physics } \\
\text { research discipline } \\
\text { opposed to the } \\
\text { Whig approach }\end{array}$ & $\begin{array}{l}\text { Advanced } \\
\text { relativistic } \\
\text { quantum } \\
\text { mechanics }\end{array}$ \\
\hline $\begin{array}{l}\text { Measure- } \\
\text { ments }\end{array}$ & $\begin{array}{l}\text { Anthropo- } \\
\text { morphic }\end{array}$ & $\begin{array}{l}\text { Heroic } \\
\text { stories }\end{array}$ & \begin{tabular}{|l|} 
State-nationalistic \\
competitions
\end{tabular} & $\begin{array}{l}\text { Scientiometrics, } \\
\text { later computerized }\end{array}$ & $\begin{array}{l}\text { Computer-web- } \\
\text { smartphone } \\
\text { related }\end{array}$ \\
\hline $\begin{array}{l}\text { Main case } \\
\text { study / } \\
\text { Topics rese- } \\
\text { arched }\end{array}$ & $\begin{array}{l}\text { Socrates' } \\
\text { affiliates, Roman } \\
\text { techniques }\end{array}$ & $\begin{array}{l}\text { New } \\
\text { branches of } \\
\text { electricity } \\
\text { and pneu- } \\
\text { matics }\end{array}$ & $\begin{array}{l}\text { Steam engines } \\
\text { and Electro- } \\
\text { technique }\end{array}$ & $\begin{array}{l}\text { Copernicus/Galileo/ } \\
\text { Newton/ } \\
\text { Maxwell/Einstein/ } \\
\text { Quantum } \\
\text { mechanics }\end{array}$ & $\begin{array}{l}\text { Extra-European } \\
\text { and female } \\
\text { scientific } \\
\text { pursuits }\end{array}$ \\
\hline
\end{tabular}




\begin{tabular}{|c|c|c|c|c|c|}
\hline $\begin{array}{l}\text { Means of } \\
\text { transport }\end{array}$ & \begin{tabular}{|l|} 
Horseback riding \\
and carriages \\
with some \\
galleys or sailing \\
boats on lakes \\
and nearby seas
\end{tabular} & $\begin{array}{l}\text { Sailing boats } \\
\text { on rivers, } \\
\text { canals, and } \\
\text { oceans }\end{array}$ & $\begin{array}{l}\text { Steam engines } \\
\text { pioneering } \\
\text { attempts: } \\
\text { railways, } \\
\text { steamers, and } \\
\text { balloons }\end{array}$ & $\begin{array}{l}\text { Internal combustion } \\
\text { cars, railways, } \\
\text { boats, planes }\end{array}$ & $\begin{array}{l}\text { Electrical } \\
\text { railways and } \\
\text { cars }\end{array}$ \\
\hline Relativity & $\begin{array}{l}\text { Anti-barbaric } \\
\text { self-awareness }\end{array}$ & \begin{tabular}{|l} 
Geogra- \\
phical- \\
religious \\
self-aware- \\
ness, \\
religion \\
separated \\
from state \\
schools
\end{tabular} & $\begin{array}{l}\text { Self-awareness, } \\
\text { Einstein's } \\
\text { relativity }\end{array}$ & $\begin{array}{l}\text { Einstein's "all } \\
\text { is relative", } \\
\text { Feyerabend's } \\
\text { "anything goes" }\end{array}$ & $\begin{array}{l}\text { Teleportation } \\
\text { possibilities, } \\
\text { Feyerabend's } \\
\text { scientific' } \\
\text { ideology globally } \\
\text { separated from } \\
\text { state schools } \\
\text { (Feyerabend, } \\
\text { 1987, pp. } \\
\text { 287-301) }\end{array}$ \\
\hline $\begin{array}{l}\text { Funda- } \\
\text { mental- } \\
\text { smallest- } \\
\text { substance }\end{array}$ & \begin{tabular}{|l|} 
Schools \\
(Pythagoras, \\
Plato's \\
Academia, \\
Peripatetic, Han)
\end{tabular} & $\begin{array}{l}\text { Geogra- } \\
\text { phical } \\
\text { regions }\end{array}$ & $\begin{array}{l}\text { National (French, } \\
\text { Japanese) or } \\
\text { mixed (Habsburg, } \\
\text { Ottoman, } \\
\text { Russian, Indian, } \\
\text { Chinese) states } \\
\end{array}$ & Civilizations/races & Networks \\
\hline $\begin{array}{l}\text { Funda- } \\
\text { mental- } \\
\text { greatest- } \\
\text { object }\end{array}$ & $\begin{array}{l}\text { Greek } \\
\text { Mediterranean, } \\
\text { Pax Romana, } \\
\text { Chinese } \\
\text { dynasties }\end{array}$ & Religions & \begin{tabular}{|l|} 
Religions, \\
Shiisms \\
(Christian-Muslim \\
of Protestant- \\
Orthodox-Catholic \\
Sunni-Shiite)
\end{tabular} & Earth-Gaea & Solar system \\
\hline $\begin{array}{l}\text { Dimensions } \\
\text { of space } \\
\text { and means } \\
\text { of measure- } \\
\text { ment }\end{array}$ & $\begin{array}{l}0,05 \mathrm{~mm}-1,000 \\
\mathrm{~km} \text { against } \\
\text { Eratosthenes' } \\
\text { circumference of } \\
\text { the Earth; steps, } \\
\text { feet }\end{array}$ & $\begin{array}{l}0,0001 \mathrm{~mm}- \\
3^{*} 6,400 \mathrm{~km} \\
\text { microscope, } \\
\text { telescope, } \\
\text { triangulation }\end{array}$ & $\begin{array}{l}\text { 0,00001 mm-106 } \\
\mathrm{km} \text {; electric }\end{array}$ & \begin{tabular}{|l|}
$10^{-15} \mathrm{~m}$ \\
(nanometric) $-10^{10}$ \\
light-years, electron \\
microscopes, \\
space travel
\end{tabular} & $\begin{array}{l}10^{-17} \mathrm{~m} \\
\text { (nanometric } \\
-10^{12} \text { light- } \\
\text { years, electron } \\
\text { microscopes, } \\
\text { space travel }\end{array}$ \\
\hline $\begin{array}{l}\text { Dimen- } \\
\text { sions of } \\
\text { time and } \\
\text { means of } \\
\text { measure- } \\
\text { ment }\end{array}$ & \begin{tabular}{|l|}
0,1 s-6,300 \\
years; gnomons, \\
water clock, \\
dynasties of Near \\
and Far East, \\
Greek tribes, \\
Roman rulers \\
\end{tabular} & \begin{tabular}{|l|}
$0,001 \mathrm{~s}-10^{6}$ \\
years; \\
pendulums, \\
spring-clock
\end{tabular} & $\begin{array}{l}0,00001 \mathrm{~s}-10^{8} \\
\text { years; electric } \\
\text { clocks }\end{array}$ & $\begin{array}{l}10^{-9} \mathrm{~s}-10^{10} \text { years; } \\
\text { electronic clocks }\end{array}$ & $\begin{array}{l}10^{-11} \mathrm{~s}-10^{12} \\
\text { years; quantum } \\
\text { electronics }\end{array}$ \\
\hline $\begin{array}{l}\text { Tools/ } \\
\text { measure- } \\
\text { ment } \\
\text { devices }\end{array}$ & $\begin{array}{l}\text { Dialectics } \\
\text { versus Euclid's } \\
\text { postulations } \\
\text { narrations/ } \\
\text { summing the } \\
\text { number of } \\
\text { convinced }\end{array}$ & \begin{tabular}{|l|} 
Devices \\
fabricated/ \\
summing \\
their number
\end{tabular} & $\begin{array}{l}\text { Industrial } \\
\text { enterprises } \\
\text { supported/ } \\
\text { summing their } \\
\text { number }\end{array}$ & $\begin{array}{l}\text { Computer-web } \\
\text { scientiometrics/ } \\
\text { citation indexes }\end{array}$ & $\begin{array}{l}\text { Networks } \\
\text { interferences } \\
\text { analysis/web- } \\
\text { connection } \\
\text { and genome- } \\
\text { memory } \\
\text { comparisons }\end{array}$ \\
\hline
\end{tabular}




\begin{tabular}{|l|l|l|l|l|l|}
\hline $\begin{array}{l}\text { Involved } \\
\text { number of } \\
\text { physicists/ } \\
\text { schools } \\
\text { considered }\end{array}$ & $100 / 12$ & $200 / 12$ & $1,000 / 20$ & $10,000 / 30$ & $100,000 / 6$ \\
\hline $\begin{array}{l}\text { Information } \\
\text { transfer }\end{array}$ & Classical letters & $\begin{array}{l}\text { Journals, } \\
\text { optic } \\
\text { telegraphy }\end{array}$ & $\begin{array}{l}\text { Electromagnetic } \\
\text { telegraphy }\end{array}$ & $\begin{array}{l}\text { Marconi's wireless; } \\
\text { web }\end{array}$ & $\begin{array}{l}\text { Smart phones, } \\
\text { Space worms }\end{array}$ \\
\hline $\begin{array}{l}\text { Energy } \\
\text { used/ } \\
\text { energy } \\
\text { transfer }\end{array}$ & $\begin{array}{l}\text { Wood- } \\
\text { accumulated } \\
\text { solar energy/ } \\
\text { mechanical }\end{array}$ & $\begin{array}{l}\text { Thermic coal } \\
\text { powered } \\
\text { steam } \\
\text { engines/ } \\
\text { steam }\end{array}$ & $\begin{array}{l}\text { Thermic- } \\
\text { chemical oil } \\
\text { powered internal } \\
\text { combustions/ } \\
\text { Edison's direct- } \\
\text { electric current } \\
\text { wires }\end{array}$ & $\begin{array}{l}\text { Hydro-electric \& } \\
\text { steam \& nuclear } \\
\text { power plants- } \\
\text { stations/Tesla's } \\
\text { alternative-electric } \\
\text { current wires }\end{array}$ & $\begin{array}{l}\text { Solar-Gaea/ } \\
\text { Tesla's wireless }\end{array}$ \\
\hline
\end{tabular}

The history of history of physics with its views from the bird's-eye perspective to the outlook of additional dimensions brings some new light to the possible directions of development of the history of physics, as well as to physics itself. The development of the paradigms of history of physics mirror the development of paradigms of physics research mostly with small delays in time and bigger differences in space when the novelties were extrapolated into non-European settings before the First World War. In the future, the domains of non-European and women researchers will certainly take the leading roles, and there is some remote possibility that the relation might turn into history of physics becoming the teacher of the physics in how to orient its future research. Such an antiWhig future could help to end the force of scientific ideology which Feyerabend despised as false prophecy. That could be a significant turn in the rivalry between physicists and their historians because some past paradigms of history of physics directly changed with only a dozen years of delay after the development of physics, which they study. For example, Priestley's history of electrostatics provided the revolutionary crisis (K1-P1) of the first paradigm of personalized history of physics in the style of Herodotus and Plutarch during the antiquities. Priestley enabled the Far-East Rangaku research of Sokichi Hashimoto, histories of steam engines, and Arago's biographies of the new growth (R2). Emil Wilde published carefully his neutral history of light research (Z2) after the (temporary) victory of waves, simultaneously with the more courageous Whewell, to enable the universalization of history of science (U2) for the other histories of steam engines and their more successful electronic descendants. Engels's antagonist Dühring, as well as Lenin's and Boltzmann's antagonist Mach's doubts (K2, P2) ended 


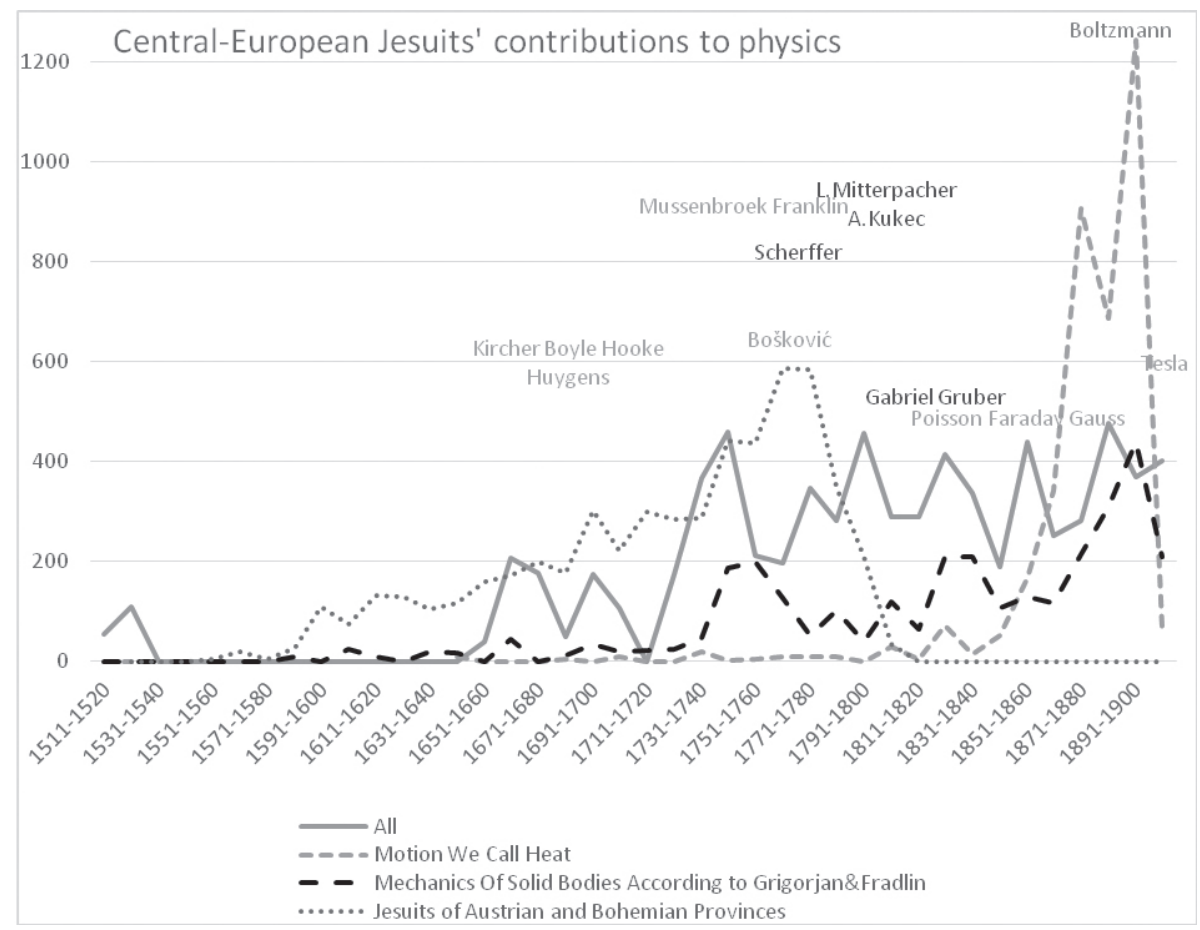

Figure 4. Central-European Jesuits' research compared to the others

the seemingly endless Poggendorff's style collections of facts. Pierre Duhem's (R3) philosophical approach and Whittaker's discussions of ether on its probable deathbed witnessed the historically extremely doubtful success of the majorityvoted Copenhagen interpretation of quantum mechanics after Einstein's and Schrödinger's more liberal short intermezzos based on their mutual sexual liberty compared to the monogamous Bohr, Heisenberg, or Dirac. Ernst Mach's godson, the divorced café frequenter Wolfgang Pauli was the enfant terrible of the Copenhagen quantum mainstream. Once upon a time, Galileo's mathematical sciences ceased to serve theology in the world created by God-Mathematician who could enter Plato's Academy should he wished so. Similarly, four centuries later, history of physics ceased to act as the maiden-propagandist-servant for physicists in spite of the recent Conant's supporting of historians of sciences. The medieval hierarchy of sciences with grammar as its basis ceased to apply and no one wanted to serve for less money if he could play a boss. If Galileo's God was a Mathematician, Marx's one was a Historian to make historians of physics proud of their values after Hessen's and Barnal's third disintegration (Z3) of the 
growth of Ferdinand Rosenberger's (R3) stamp-collection style of the history of physics. At the 1931 London meeting, Hessen's history of physics was upgraded by Merton's and Vavilov's similar Marxist approach.

\section{Conclusions}

One of the most striking discoveries of the history of history of physics describes conflicts of war as disastrous for historians of physics because no fighting side has much use for the historians of physics, except for propaganda. The same wars prove to be fruitful for the researchers of physics, certainly mostly to those physicists who were involved in technologies of weapons' production, or the extremely humiliating psychiatric-physiological research of the Holocaust victims. But the sobering comes too soon for the Übermensch and too late for their victims, because the aftermath years after the official peace do not produce much of valuable physics. Rutherford's best coworker Henry Moseley (18871915) and many others got killed in the First World War. The rule of post-war stagnation in physics applied to the Thirty Years' War (1618-1648), the War of the Spanish Succession (1701-1714), Napoleonic Wars ending in 1813/14, French-Prussian War with the Paris Commune, the First and the Second World Wars. The War for the Spanish Succession and both twentieth-century world wars also coincided with immense scientific efforts of pioneering Newtonians against their antagonistic Leibniz's followers, or the quantum-relativistic researchers. The tremendous war efforts exhausted or even handicapped the next generations, and science was forced into stagnation. In all these cases, (applied) physics prospered during the fighting and declined in the aftermath, while history of physics disappeared in war battles and prospered in the aftermath in Conant-like propaganda efforts for the rise of public opinions about science. The applied-technological-industrial physics follow similar ups and downs, as do experimental or theoretical physics, because the physics of warfare does not match our criteria of physics technology proper. The history of history of physics follows different paths and there is also a huge difference between the history of physics technology and the history of experimental or theoretical physics. Partington, Cummings, or Chinese Yuan Ruan in the 1820s and again Jones or Burns in the 1850s provided the peaks with their histories of steam engines and with Brewster's biography of Newton. Their contemporary physics or history of physical theories and experiments did not prosper that much in spite of Brewster's biography of Newton. Those achievements of the historians of technologies were 
clearly the echo of past events in the advances of technology, on which they reacted with the expected delay, and in the case of steam engines probably also with respect to the patent rights of the inventors involved. The inventors did not like their innovations to become public too soon.

Gevorkyan and Fradlin completed the list of all contributions in the mechanics of solid bodies with 1,003 items published before the 1904 Japanese-Russian war, and followed a similar path as all scientists except for the Thirty Years' War when the mechanics of solid bodies was in its pioneering stage without enough publications to enable any relevant judgement upon their dynamics. Another exception was the single broadened peak a dozen years after the peak of total contributions following the War of the Spanish Succession, and twice as much space of time before the peak during the French Revolution in total contributions, which had no significant output in the field of mechanics of solid bodies (see Fig. 1 on p.11). The peak of the post-Napoleonic period, the stagnation during the Spring of Nations, and the following peak seems to be the same. The total output of research of the motion we call heat with 674 items published before the $20^{\text {th }}$ century rapidly grew after the Spring of Nations, but no other dynamic particularities are evident. The output of Jesuit physics in Central Europe behaved very similarly to the total output of the Jesuits. The Central-European Jesuits Erasmus, Frölich and Halloy supported Musschenbroek's peak after the Spanish War of Succession, and Scherffer corresponded to Euler, with Scherffer's friend Bošković filling the gap in-between. The research of mechanics by CentralEuropean Jesuits or their total input provides relatively good correspondence to the total output of mechanics of their day. The physics of Jesuits was later viewed as in opposition to its contemporary mainsteam physics, but they both certainly provided the same output dynamics with the Graz Jesuit Kepler's friend Paul Guldin's peak during the Thirty Years' War, the post-Newtonian and post-Spanish-Succession-War gap, and the Bošković and Scherffer peak before the French Revolution, which remained unfinished because the suppression of Jesuits ended their great successes in sciences.

Social revolutions like the Spring of Nations with sudden mass involvement in politics stopped people from researching both physics and history of physics. Even Arago felt obliged to get his ministers' chair during the Spring of Nations, and Galois fell victim to the turmoil after the French July Revolution of 1830. On the contrary, the French Revolution of 1789 seems to have brought a quarter of a century of prosperity in the research of physics, especially in applied chemistry, while the history of physics also progressed regardless of the fact that no period in 
history had seen so many physicists and mathematicians involved in high politics like Lazare Carnot, Laplace, Monge, Count Berthollet of Arcueil, or the Paris Mayor and astronomer Jean Sylvian Bailly. No one makes relevant science with a gun in his hand, except for producers of weapons, and every military conflict ruins the local economies in the following times of peace.

It is much more difficult to estimate how many new ideas popped up in physics and its history as a result of the war conflicts and mixing of different cultures, for example during the great marches of Alexander the Great in Persia, Egypt, and India, or the Napoleonic expeditions in Egypt or Russia. The Hellenic Post-Alexandrian period was certainly fruitful. The Napoleonic Egypt enabled Champollion's Rosetta Stone and Champollion's Grenoble benefactor and the ancient member of Napoleonic Egyptian expedition, Joseph Fourier, to become instrumental in the future histories of Egyptian sciences. Even Napoleon's disastrous Moscow winter may have given some additional insights to the captured officer Jean Victor Poncelet in 1812-1814, or later to the St. Petersburg professor of engineering Clapeyron in 1820-1830.

\section{References}

Asimov, I. (1978), Biographical Encyclopedia of Science and Technology, London: Pan Books, Ltd.

Bogolyubov, A. N. (1983), Matematiki, Mekhaniki: Biograficheskii spravochnik, Kiev: Naukova dumka.

Brush, S. S. (1976), The Kind of Motion We Call Heat, Amsterdam, New York \& Oxford: North-Holland.

Chimisso, C. (2016), Writing the History of the Mind: Philosophy and Science in France, 1900 to 1960s, Abingdon: Routledge.

Collins, R. (1998), The Sociology of Philosophies; The Global Theory of Intellectual Change, Harvard: Harvard University Press.

Conant, J. B. (1955), 'The Citadel of Learning,' The Yale Review, vol. 45, pp. 48-61.

Feyerabend, P. (1987), Protiv metode, Sarajevo: Veselin Masleša. [Original: Feyerabend, P. (1975), Against Method, London: New Left Books.]

Grigoryan, A. T. \& Fradlin, B. N. (1982), Istoria mekhaniki tverdoga tela, Moskva: Nauka, pp. 216-257;

Jammer, M. (1957), Concepts of Force: A Study in the Foundations of Dynamics, Harvard: Harvard University Press. 
Khramov, Yu. A. (1977), Fiziki: Biograficheskii spravochnik, Kiev: Naukova dumka.

Lukács, L. (1988), Catalogus generalis seu Nomenclator biographicus personarum Provinciae Austriae Societatis Jesu (1555-1773), Rome: Institutum Historicum S. I.

Mach, E. (1894), Beiträge zur Theorie der Ton- und Farbeänderungen durch Bewegung, Leipzig: Barth.

(1909), Die Geschichte und die Wurzel des Satzes on der Erhaltung der Arbeit, Leipzig: Barth.

— (1919), Die Principien der Wärmelehre, $3^{\text {rd }}$ ed., Leipzig: Barth. (1912), Die Mechanik und ihre Entwicklungen, $7^{\text {th }}$ ed., Leipzig: Barth.

Rothenberg, M. (2001), The History of Science in the United States, New York \& London: Garland.

Segre, M. (1998), 'The never-ending Galileo story,' in P. Machamer (ed.) Cambridge Companion to Galileo, Cambridge: Cambridge University Press, pp. 388-416. https://doi.org/10.1017/CCOL0521581788.012

Sommervogel, C. (1890-1900), Bibliothèque de le Compagnie de Jésus, Bruxelles-Paris: Province de Belgique.

Stoeger, J. N. (1855), Scriptores Provinciae Austriacae Societatis Jesu, Wien.

Stanislav Južnič was born in San Francisco and obtained US and Slovenian citizenship. During his studies he worked at the University of Minsk in Belarus, which enabled him to understand better Augustin Hallerstein's relation with the Russian Academy and Gabriel Gruber's work in Russia. He graduated from the Physics Department and studied the history of eighteenth-century physics with academician Vasilij Melik at the Department of History of the University of Ljubljana. After obtaining his $\mathrm{PhD}$, he returned to USA, where he worked in the Film Library of the Jesuit University Saint Louis, MO, and at the Science Department, University of Oklahoma, researching simultaneously also at the Institute for Mathematics, Physics, and Mechanics in Ljubljana, at the Scientific Research Centre of Slovenian Academy of Sciences and Arts, and as the head of Slovenian Jesuit Archives. He has published about one thousand research works (articles, books) in Chinese, and almost all European languages in China, Japan, USA, Australia, Russia and many European countries. His contemporary research is connected with Rudjer Bošković and Nikola Tesla networks, showing how Tesla's electronics emerged from the ideas of the Jesuit teachers of his teachers.

For decades, he collaborated with Ljubljana Jesuits, trying to put in the limelight the achievements of the Ljubljana Jesuit physicists. Among his recent monographs are the one on Hallerstein, a Chinese astronomer from 
Mengeš (2003, English translations 2014, Chinese translations 2015 and 2016), and the three-volume History of the Vacuum Research and Vacuum Techniques (2004, 2009, 2016). For the International Year of Astronomy 2009 he finished his trilogy about the history of exact sciences in Slovenia. He prepared the history of Franciscan physics and related sciences for the $800^{\text {th }}$ anniversary of the Franciscan order in 2009. 